\title{
Violence in Peru: Performances and Dialogues
}

Billie JeAn IsBell

Cornell University

GUADALUPE CCALLACUNTO WAS dragged from her parents' home in the city of Ayacucho about 2:30 a.m. on June 10,1990, when she returned from Lima to vote; I dedicate this work to her. In 1983-84 her husband and brother-in-law were disappeared, along with
51 others, from the village of Quispillaqta, district of Chuschi, province of Cangallo, department of Ayacucho. As a young mother of two small children, Guadalupe had become active in the work of the Committee of the Families of the Disappeared in the Emergency Zone and in Serpaj International, a Catholic human rights organization. Her name appeared on Amnesty International's 
Rapid Response Network in 1990. She is presumed dead. I read this dedication for the first time in New York City on December 1990, at Columbia University, and then again in London at a conference at Kings College in 1991. It was repeated at a conference at Rutgers University in 1992. I traveled with the Quilt of the Disappeared and read the same dedication at the University of California at Riverside and at the University of Utah in 1993. When my play Public Secrets from Peru was given a concert reading at Cornell in 1994, I dedicated it to Guadalupe.

I also dedicate this work to Martín Cayllahua, Marcel Cabana, and Isias Huamán, the elected officials who were disappeared by masked and hooded men during the night of March 14,1991, in the village of Chuschi, department of Ayacucho, Peru. They refused to form the obligatory civil patrols, and their disapearances are attributed to the national police officer in charge of the Chuschi post, Alfarez Bobadilla Cuba. He is alleged to have threatened to disappear anyone who refused to participate in the patrols. Their case was brought before the Peruvian congress, but no action was taken due to President Fujimori's unilateral disbanding of the congress on April 5, 1992. I first learned of their disappearances while presenting a paper in London in 1991 and subsequently added their names to my dedications.

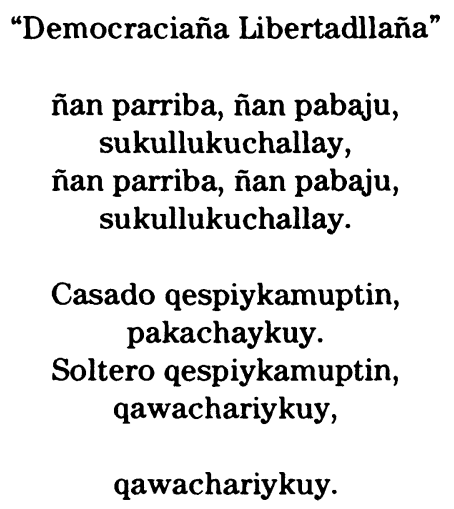

Imallataq kunanqa rikurillanchu. Imallataq kunanqa rikurillanchu.

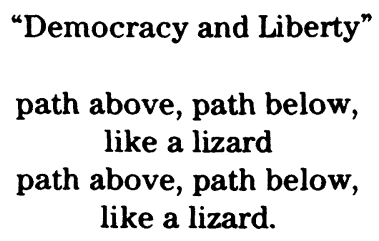

When a married man suddenly appears, we take cover.

When a single man suddenly appears, we watch out,

we take care.

"It's said there's democracy and liberty now," you tell us.

"It's said there's democracy and liberty now," you tell us.

But this fine liberty is fatal to us.

This good democracy brings prison and death.

Whom have I offended so? Where have I done harm?

They arrived at my village and took him prisoner.

They carried off my beloved husband to disappear him forever.

In the plaza of Chuschi, two little doves.

In the plaza of Chuschi, two little doves.

What appears there now?

What has taken their place? 
Rikurillanchu.

Rikurillanchu.

Wakinchá carcelpi, wakinchá allpapi.

Wakinchá carcelpi, wakinchá allpapi.

Pitaraq ñakachkan.

Maytaraq ñakachkan.

Pitaraq ñakachkan.

Maytaraq ñakachkan.

Pitaraq ñakachkan.

Over the past five years I have begun public presentations about political violence in Chuschi, Peru, with dedications and songs like the ones that open this essay. It is my intention to create a lament, a commemorative text. One of my objectives is to situate my knowledge (Haraway 1991). Another is to place my own practices on the same dialogical ground (Mannheim and Tedlock 1995:19) with performers in Peru. I wish not only to influence my readers' perceptions of the political violence that has shaken Peru in the last decade and a half, but also to transform the relationship of researchers to such events and the rules of academic discourse about such events. I find it remarkable that there has been relatively little academic discourse on the aftermath of the war. Only a few young researchers are addressing these issues (Theidon and Del Pino 1997).

As anthropologists, we share with Peruvian musicians our engagement in public performances and our construction of dialogues. We address audiences, make commentaries, and engage in "world making." The performers of "Democracy and Liberty" are engaging in what John Attinasi and Paul Friedrich (1995) have called a "dialogic breakthrough," in which the "dialoguing imaginations" of the performers and listeners provide a catalyst for change. The song is constructed as an imaginary dialogue with power and illustrates the situated discursive practices of Quechua speakers. Like my dedication, it commemorates the disappeared elected officials and comments on democracy. This song, which first appeared in 1991-92, quickly passed from one performance group to another. Facilitated by the informal tape industry, it spread throughout the Ayacucho Department and beyond, to refugee settlements within and outside of Peru. My analysis of this song, presented as a dialogue alongside my dialogues with creators of protest art, is the result of a cathexis, a realignment of my thinking which resulted in a lifechanging experience in my practice of anthropology.

The protest songs and art will not be analyzed in terms of subaltern art and hegemonic texts or in any of the usual oppositions such as traditional-modern, but
What reappears there now? What reappears there now?

Some might be in prison and others in the ground. Some might be in prison and others in the ground.

Who is damning us? How much longer will we be cursed? Who is damning us? How much longer will we be cursed? Who is damning us?

rather in terms of hybridization in the exchange of ideological and cultural goods. Hybridity is "fragmentation and multiple combinations among tradition, modernity, and post-modernity," and it "is indispensable for considering the Latin American conjuncture at the end of the century" (García Canclini 1995:264). Postwar Peru is especially amenable to the framework that Nestor García Canclini advocates. He argues that the current reorganization of culture(s) is not a linear process but rather a struggle over symbolic capital and cultural goods with multiple actors and decentered and multidetermined sociopolitical relations:

The cultural reconversions that we analyzed reveal that modernity is not only a space or a state one enters into or from which one emigrates. It is a condition that involves us, in the cities and in the countryside, in the metropolises and in the underdeveloped countries. With all the contradictions that exist between modernism and modernization-and precisely because of them-it is a situation of unending transit in which the uncertainty of what it means to be modern is never eliminated... . At this point it can be perceived how wrong the notion of postmodernity is if we want to avoid having the post designate an overcoming of the modern. Can we speak critically about modernity and search for it at the same time that we are passing it by? If it were not so awkward, we would have to say something like post-intra-modern. [1995:268]

García Canclini is not referring simply to "multitemporal heterogeneity" of the "traditional" and the "modern," as asserted by Renato Rosaldo in the foreword to the English translation (1995:xi-xvii). Rather, he explicitly criticizes such dichotomies and totalizing superparadigms, as well as descriptions that omit "ambiguous processes of interpenetration and mixing in which the symbolic movements of different classes engender other processes that cannot be ordered under the classifications of hegemonic and subaltern, modern, and traditional" (García Canclini 1995:199). Hybridity rejects these temporalities, as well as the implied evolutionary thrusts of development and polarities. García Canclini's concept of hybridity is especially productive when applied to contestatory 
discourses and forms of protest that have become cultural goods on the transnational market in the aftermath of the years of war in Peru.

\section{Protest Songs and Oblique Power Relations}

From one point of view, "Democracy and Liberty," which is a constructed dialogue between a woman and a government authority, is an example of counterhegemonic expression of solidarity. The singer, using the exclusive first-person pronoun, speaks for a collectivity that challenges the repeated assertion "It is said there is democracy and liberty now." From another point of view, however, the song decenters the speakerlistener relationship. The performers situate their own knowledge in a different political space from authorities. The singer does this by declaring that "this good liberty and democracy come to us with prison and death," but she also does it by using the topic marker -qa to indicate direct experience with "this good democracy." Her assertion contrasts to the previous stanza, in which she marks the authorities' assertion as hearsay. By using a formal aspect of Quechua grammar to differentiate between hearsay and experiential validity, the

\section{"Chinkaqkuna" \\ Señor Fiscal, papallchay, chawpi tuta uran,}

piyan wawallaytan urqorqamun manan reqsisqay runakuna.

Chaymin willakukniyki hamuni, maskaykaysillanawaykipaq.

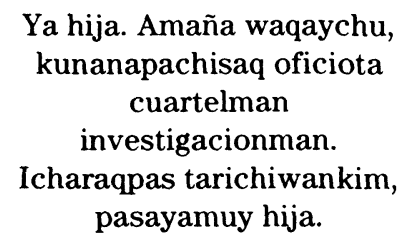

Ya papalláy.

Urqo qasanchalla purimuchkani. Llaqtan llaqtanchalla purimullachkani. Kuyay wawallayta maskallachkani.

Kuyay churillayta maskamullachkani.

Chisichin lucero kachaykamullaway.

Achikyan lucero kachaykamullaway.

Kuyay wawallayta maskaykachallaway. Kuyay churillayta maskaykachallaway. singer questions the touted democracy of Peru. Her discourse then moves to a personal lament as she recounts the disappearance of her beloved. She is referring to the disappeared elected officials eulogized in the dedication. The song is not simply a counterhegemonic practice directed toward other Quechua speakers. More importantly, it is an oblique dialogue with those in power, most of whom do not speak Quechua.

The stanza that begins the song is a metaphorical warning to be wary of the unknown. The lizard is the transformed disguise of unknown agents such as foreigners or supernatural beings. The song warns of all unknowns: married men, single men, anyone. Another protest song, "Chinkaqkuna" (The Disappeared), spoken and sung in Quechua, represents (again with irony) the discourse between a woman petitioner and a judge. While the borrowed Spanish term desaparecido is found in the Quechua lexicon, this song uses the Quechua term chinkaqkana, which has an interesting association with chinqana, places where one can lose oneself. These are usually configured as underground labyrinths or caves (Thomas n.d.). Is it possible that political disappearances carry a spatialized connotation?

$$
\begin{gathered}
\text { "The Disappeared" } \\
\text { (spoken by a woman petitioner) } \\
\text { Mr. Judge, Mr. Judicial Authority, } \\
\text { Padre, father, } \\
\text { last night at midnight, } \\
\text { unknown men, } \\
\text { strangers, took my son. } \\
\text { That's why I've come to let you know, } \\
\text { so you can help me find him. } \\
\text { (she sobs) } \\
\text { Now daughter, don't cry. } \\
\text { Today I'm going to send an official } \\
\text { memo to the barracks, } \\
\text { to the section of investigation. } \\
\text { Perhaps we'll be able to find him. } \\
\text { Go along, daughter. } \\
\text { (spoken by the woman) } \\
\text { Yes, kind sir. } \\
\text { (sung by the woman) } \\
\text { From hill to hill I keep walking. } \\
\text { From town to town I keep walking. } \\
\text { I keep searching for my beloved child. } \\
\text { I keep searching for my beloved son. } \\
\text { Evening star, shine on me. } \\
\text { Morning star, give me your light. } \\
\text { Help me look for my beloved child. } \\
\text { Help me find my beloved son. }
\end{gathered}
$$


Ima tristi wawa churinchik pirdikuy!

Kay diyapeqa aswan sasallaña.

Killan intiru purimullasqaypi.

Watan intiru maskamullaqaypi.

Manamç tarinichu kuyay wawallayta.

Manamç tarinichu kuyay churillayta.

Wamanga llaqtapi, wiraqocha fiscal, Wamanga llaqtapi, wiraqocha fiscal, kuyay wawallayta rikurichimullay. Kuyay churillayta rikurichimullay.

Ujalayá kay takinchista, gobierno uyariykawachkan.

Wasa wasiytapas qawarqamuniña. Kaylla wasiytapas maskarqamuniña. Manamá tarinichu kuyay wawallayta.

Manamá tarinichu kuyay churillayta.

Infiernilllutapas qhawarqamuniña. Cuartil kuchutapas maskarqamuniña, manamá tarinichu kuyay wawallayta. Manamá tarinichu kuyay churillayta.
How sad to lose our children!

These days are so hard.

I've walked this whole month. I've searched during the entire year. But I haven't found my beloved child. I haven't encountered my beloved son.

Mr. District Attorney of Humanga, Mr. Judge of Humanga, make my beloved child appear. Make my beloved son appear.

(spoken by the judge)

May the government listen to our sad song.

(sung by the woman)

I went to the house behind mine and to all the houses nearby.

But I haven't found my beloved child.

I haven't found my beloved son.

I've also looked at Infiernillo.

I've searched at the garrison and

I haven't found my beloved child.

I haven't found my beloved son.
Again the song is grammatically marked to communicate the validity of firsthand experience. It is as if the mother of the son (or daughter) were speaking to the judge or district attorney in charge of taking depositions on disappearances. By chance, the place-name Infiernillo (Little Hell) aptly describes what was actually found there. Francisco Huamantinco Cisneros quotes a University of Huamanga professor, a former student leader who was detained several times and almost disappeared, as saying, "The things we have seen seem to have been taken from a Kafkaesque novel. Pigs eating a human cadaver, dogs dragging an arm, a head" (1990: 36). Such is his description of Little Hell, the site where the remains of disappeared and assassinated students from the university were found. "Chinkaqkuna," first sung and recorded in Ayacucho, became popular in 1992-93 in Lima, among the scattered settlements where close to 200,000 refugees from the Andean region live.

Little Hell has become a powerful mental landmark in the mapping of social memory. It contributes to cultural hybridity through the combination of its status as a place made sacred by the rituals of the region (Isbell 1985) with the horrific mapping of massacres and disappearances. This new geographical configuration of memory and practice cannot be categorized as traditional, modern, postmodern, or premodern. The story is related with the narrative authority of the eyewitness and communicates the validity of experience over bureaucratic hearsay. One of the most important vehicles for constructing memories of the events is the invocation of geographic locations. None of the song texts I have analyzed draw graphic images of torture or disappearances. Rather, localities such as Infiemillo encapsulate horrific experiences and become emblematic in the process of re-creating and remembering the events. The audience must know and imagine why a place is significant. This becomes especially important if we recall that the earth is a living being for Andean people and that localities such as Little Hell are animated. We would learn a great deal about the dynamic relationships between subjectivity, memory, and history by interviewing people about such places. One of the things I am sure we would learn is that they act as subjects, becoming important actors in the reshaping and retelling of events. Songs about these places are part of an extensive discourse that remains invisible to and unheard by Lima's Spanish-speaking middle and upper classes, who are currently celebrating the return of international capital and what has become the most rapidly growing economy in Latin America.

\section{The Culture Industry and Protest Folk Art}

Over the last 15 years, new protest arts have memorialized the realities of victims of the war in Peru. I 
will briefly discuss three of these: arpilleras (cloth pictures), tablas (painted panels), and retablos (threedimensional boxes). They have become vehicles of protest for those who have become deterritorialized (García Canclini 1995:228-229). Their "natural" relation to their geographical and social territory has been lost, but they have become reterritorialized, even globalized. The displaced have produced old and new art that has become transnational goods on the culture market. Tablas and retablos both have long traditions in Ayacucho, but arpilleras were first made by Chilean women to publicly protest the disappearances of their loved ones. Guadalupe Ccallacunto told me that she and other Peruvian refugees who were given sanctuary by the Vicario de Santiago brought the art back to Peru, where it quickly spread among women's groups in Lima. One such group, COFADER (the Peruvian National Committee of Relatives of the Detained, Disappeared, and Displaced), was inspired by the AIDS quilt created in the United States to collectively produce a Quilt of the Disappeared, with 36 stitched stories that commemorate disappearances, detentions, and massacres. With support from the World Council of Churches, this quilt was exhibited at human rights conferences in the United States in 1993. Even though arpilleras are made for foreign consumption, their production has become a vehicle for solidarity as women collectively stitch stories of their displacment.

I purchased a collection of arpilleras in 1991, and at first glance they have the charm associated with folk art: bright colors, whimsical figures, childlike representations. On closer inspection, however, the graphic scenes of violence are shocking. The arpilleras created by members of the Vaso de Leche (Glass of Milk) program in Santa Rosa, one of the refugee settlements in Lima, focus on the army headquarters outside the provincial capital of Cangallo in Ayacucho Department. Two icons of power predominate in their depictions of violence. One of these is a large, orange radio tower, placed at the center of many scenes. For arpillera makers, the tower is something like a "postintramodern" version of Foucault's opticon. Women told me that the tower is always listening. It transmits messages that bring the helicopters and troops. The helicopter is the other predominant icon. Like motorized condors, helicopters are shown snatching victims away. In one scene, for example, a green helicopter is in the foreground, and armed men are loading bound captives; two helicopters hover overhead, one with a man, also bound, dangling by a rope underneath. The creator of this arpillera explained: "The helicopters then fly over the mountains and the soldiers cut the rope; the man falls into a ravine, never to be found, asi desaparecido." According to the cooperative members, European nongovernmental human rights organizations dis- tributed and sold the arpilleras in England, France, Germany, Italy, and Spain. It would be enlightening to follow these new symbolic goods to their transnational markets and document transformations of meanings as they are displayed in museums, used in human rights events, or sold as folk art.

The tabla, originally a three- or four-foot-tall rectangular picture painted on wood and plaster to commemorate familial rituals, is from Sarhua, a community located across the Pampas River from Chuschi, in Victor Fajardo Province. When a marriage is depicted, the table represents a kind of pictorial genealogy and is displayed prominently in the home of the newlyweds after the wedding (Araujo 1993). During the 1980s and 1990s, displaced tablistas in Lima painted scenes of violence with captions explaining the picture to the viewer, usually a foreigner. The example illustrated here is titled Maldecidos (The Cursed) (Figure 1), and the caption reads as follows:

Maldecidos

En diferentes comunidades y caminosla ciudad los maldecidos militares aprenden a golpes y patadas a los hinocentes indefensos campesinos en busca a los malhechores intrusos mal de rabios terroristaslos apresados sedientos y hambriento simimuertos son conducidos a la cuidad para ser jazgados por elementos que no conocen.

The Cursed

In different communities and roads-

[and] in the city, the swearing military, hitting and kicking, capture innocent peasants who have no defenses.

The military are looking for the evil, intrusive terrorists sick with rageare taken to the city

to be judged by elements who do not know them.

Below the caption, one man with his hands tied behind his back is forced to drink a venomous liquid while others are dragged by their hair or kicked in the face. A woman is attacked, and a man's head is stomped while an overcrowded truck waits to haul the prisoners away. The tabla makers, who have gone through the dual process of deterrorialization and relocation in Lima, are making reference to traditional meanings while also referring to the violence that has displaced them from their cultural homeland. As products of the transnational culture industry, the tablas take on new meanings in the hands of a multiplicity of interpreters. Moreover, the artists' relations to the transnational culture industry transforms their reinterpretations of the violent events of the last decade.

A last example of visual protest art is provided by retablos, which have a long tradition in Ayacucho and 


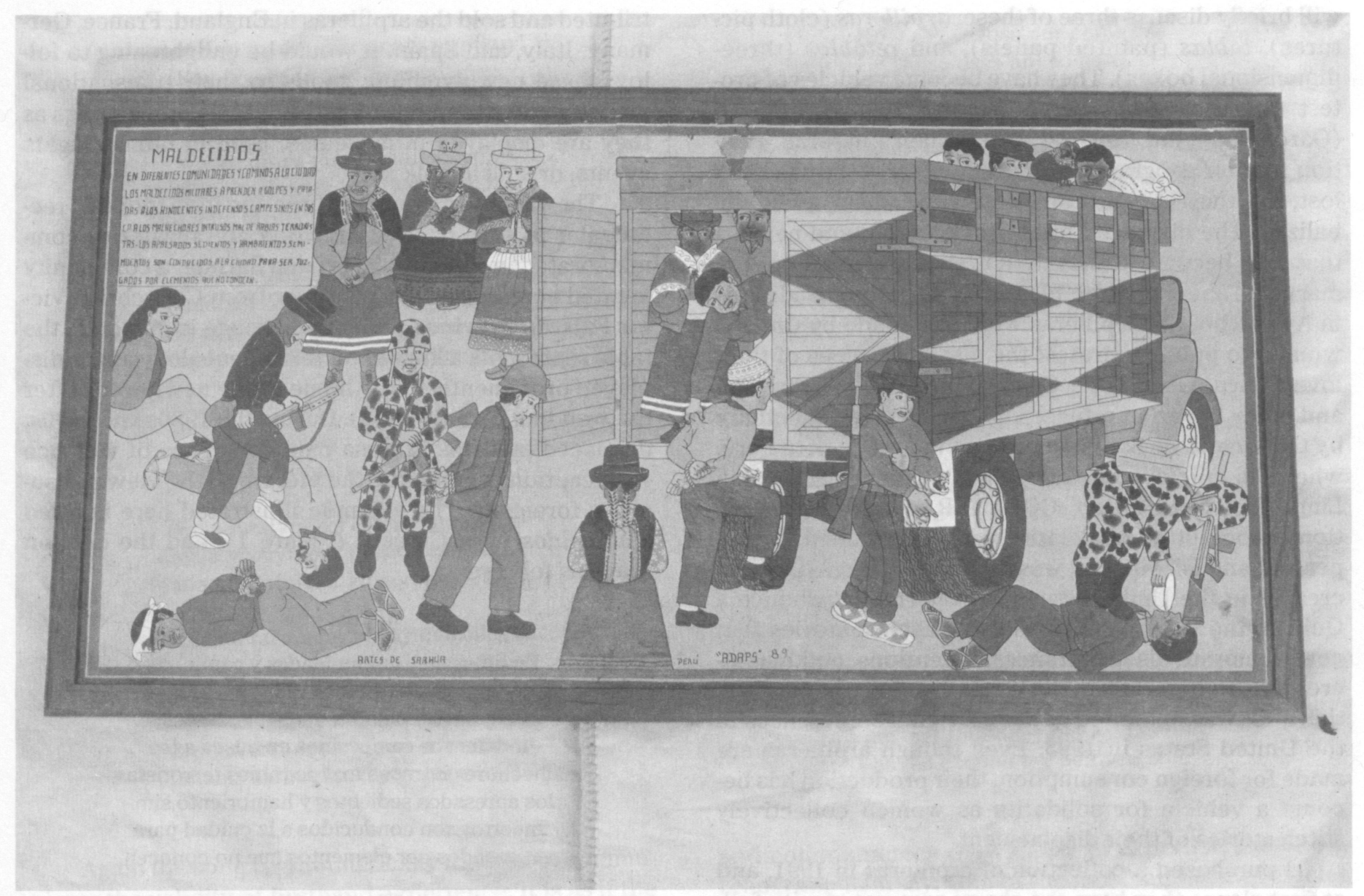

Figure 1

Tabla: The Cursed. Photo by Billie Jean Isbell.

were a favorite tourist art in the past. Like the displaced tablistas, renowned retablo artists turned to political commentary in exile. Nicario Jimenez Quispe, who now lives in Florida, tours universities and museums in the United States, Canada, and Europe with his retablos. While I was attending a meeting of the Inter-American Foundation in Washington, Charles Claymyere showed me a retablo that was purchased by a staff member in a Georgetown shop. This retablo, by Severo Yaranga, is titled Sendero Luminoso en Ayacacho. It is about four feet high and three feet wide, with four scenes. The one at the top shows Sendero Luminoso (Shining Path) attacking peasants. The Senderistas are depicted in red hoods with hammers and sickles on them (Figure 2). Above, the sun looks through the mountain pass and cries blood. The level below shows the Senderistas attacking a national guard post. The commentary by the artist on the back explains that the Shining Path was repelled, with dead and wounded on both sides, and that women Senderistas were killed. The third scene (Figure 3) shows a Peruvian air force helicopter and nurses picking up wounded sinchis (special antiterrorist forces). Among the observers are a newspaper correspondent and a television cameraman. The bottom level shows sinchis rounding up peasants who do not have their documents. A condor (the mountain god) looks down on the scene. Women weep as their family members are taken away (Figure 4).

These retablos and the other forms of protest folk art contain more than memories. The transformations and crossings created by the dislocation of the artists and the symbolic productivity of the transnational culture market generate multiple, simultaneous, and interpenetrated readings. None of these readings can be clearly labeled as "traditional," "modern," or "postmodern." Applying García Canclini's perspective, it is far more fruitful to think of them as creating new and complex power relations that are not only interwoven but also oblique and decentered rather than vertical, hegemonic, and subaltern. I am suggesting that examining the processes of creating, performing, selling, and interpreting protest art provides a means for understanding 


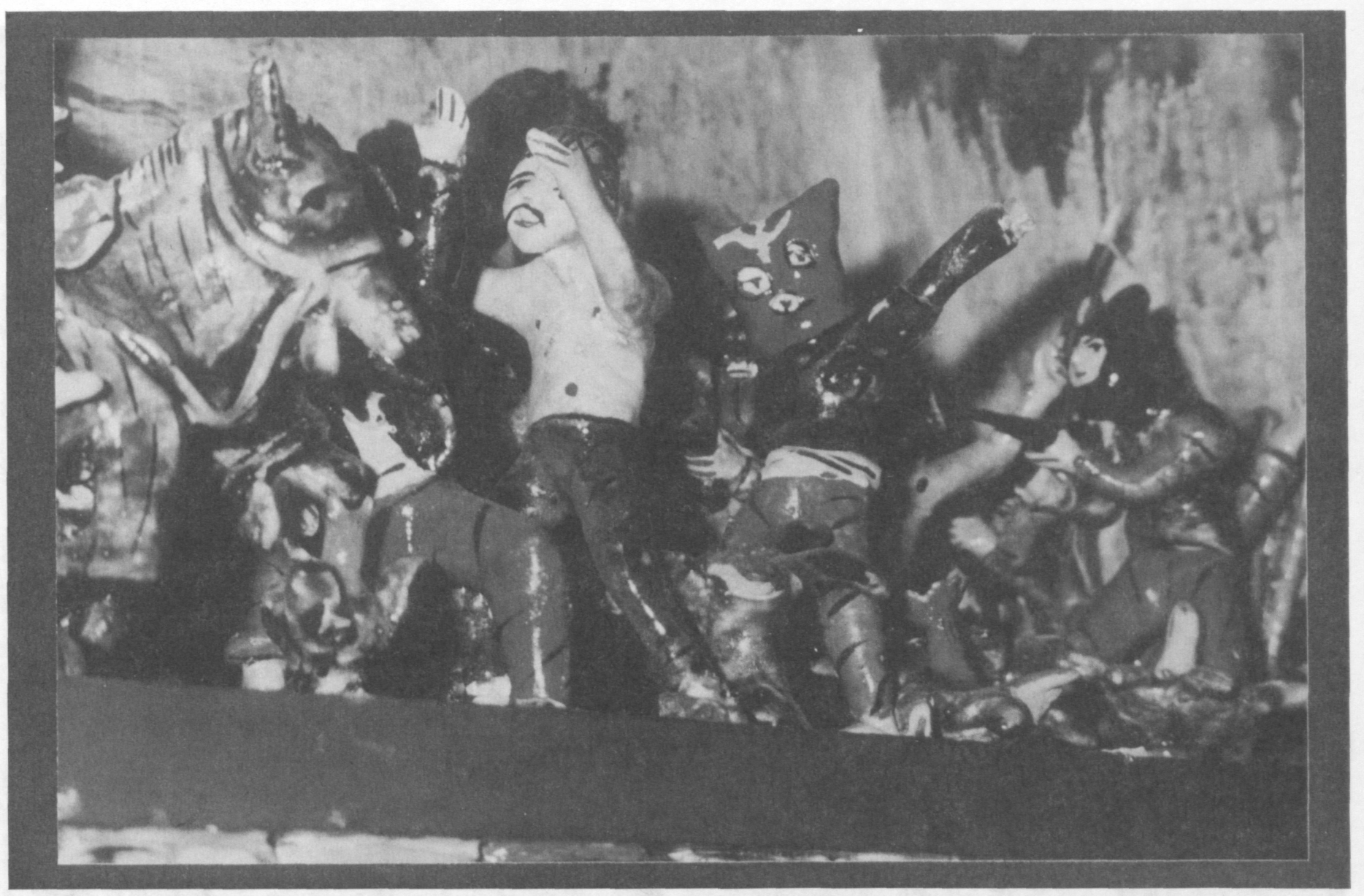

Figure 2

Hooded Senderistas attacking peasants. Detail from retablo Sendero Luminoso en Ayacacho, by Severo Yaranga. Photo by Billie Jean Isbell.

the power relations now being created in Peru's postwar environment. By taking such an approach we should be able to move beyond the Foucauldian conception of power as vertically imposed by institutional structures.

\section{Forced Forgetting and the New Dialogue of Development}

When I returned to the city of Ayacucho and the village of Chuschi in the summer of 1996 , I was interested to see whether any forms of protest art and music were visible there. I found none: no retablos, tablas, or arpilleras showing scenes of the war. They were replaced by the usual tourist fare, and arpilleras were notably absent. There was no graffiti on the walls, no slogans, no flags in the countryside. On the way to Chuschi, I noticed that the villages along the road through the Pampas Valley had electricity and piped-in water; the concrete aqueducts of an irrigation project ran alongside the road. New plazas with statues of heroes of the war of independence graced the villages that had been hardest hit by the violence. There was no commemoration of the years of warfare or the dead, disappeared, or displaced. When I arrived in Chuschi, I found the guard post the village requested in 1986, for protection against Shining Path attacks. When I asked the young mayor how the situation was in Chuschi, he said, "Everything has been peaceful since 1986, when the guardia arrived. Now we are progressing." I asked, "What about the four elected officials who were disappeared in 1991 by the guardia?" His answer was a shrug, as he turned and gave commands to the varayoq, the so-called traditional authorities who were repairing the plaza.

Next I visited the new two-story school located on the site of the old cemetery, which had been bulldozed. I was told that any family who wanted to move their dead were able to rebury them up on the hillside at a new site. The past was removed, and progress in the form of education has taken its place. The new school 


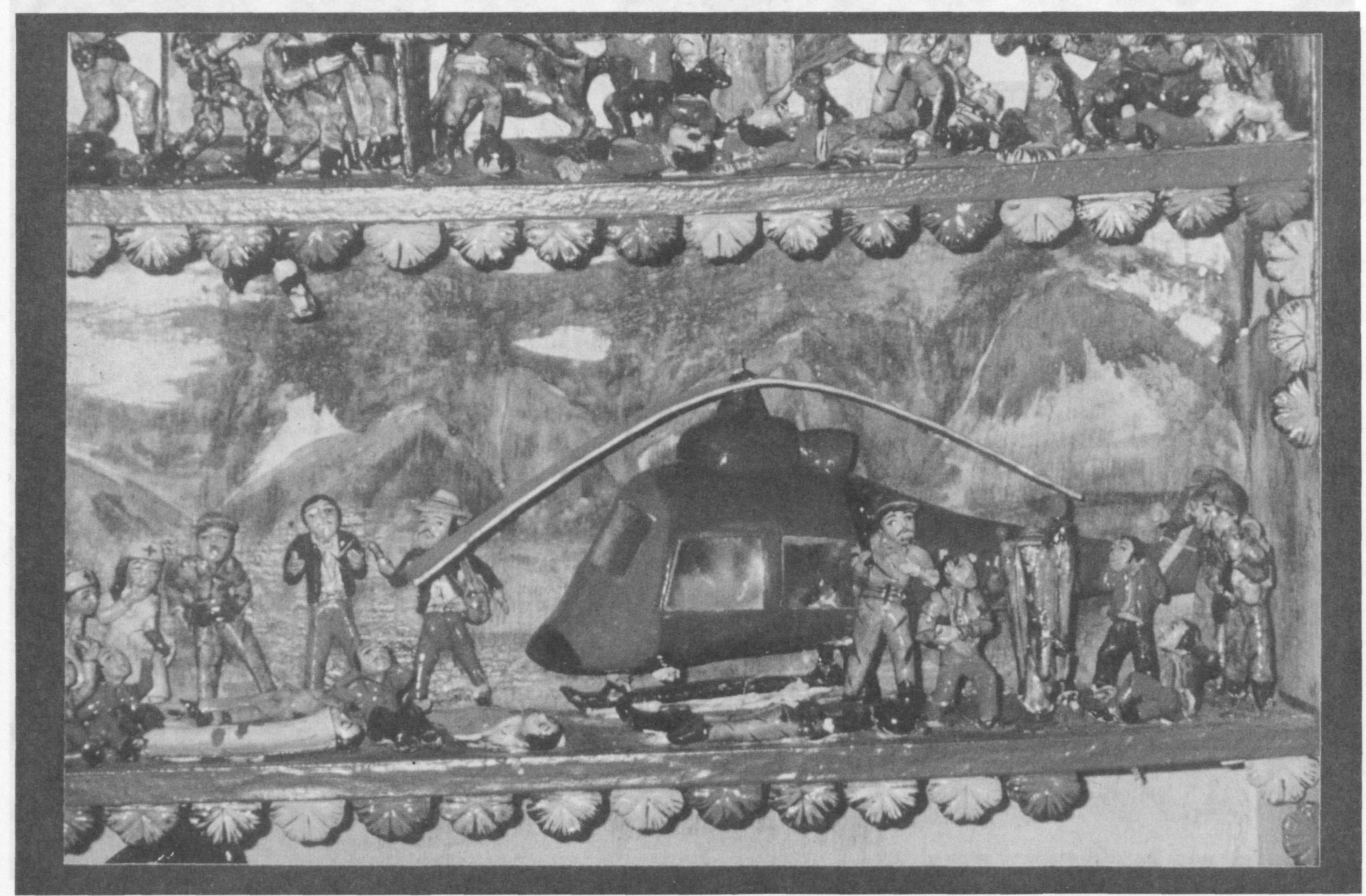

Figure 3

Helicopter picking up wounded. Detail from retablo Sendero Luminoso en Ayacacho, by Severo Yaranga. Photo by Billie Jean Isbell.

lacks teachers, desks, and books. This empty school reminded me that unfulfilled promises concerning education were one of the strongest motives for supporting Shining Path in the early days of the war. But Shining Path's own unfulfilled promises about the "new democracy of Peru" caused this support to disappear after the first three years (Isbell 1992, 1994). On market day I had lunch at one of the few stalls set up for the occasion, chatting with the women congregated there. They asked me about my mother, now deceased, and my daughter, now grown. I asked how things were, and they replied, "Sad. We are always sad. We have suffered too much." Kimberly Theidon and Ponciano Del Pino (1997) completed a study on mental health in the southeastern part of Ayacucho Department. They interviewed and held focus-group discussions with 99 men, 112 women, and 91 children in 12 communities, including Chuschi. They found that 89 percent of the men and 91 percent of the women suffered from tristeza (sadness) over their lost loved ones, their poverty, and violence and death. They also found that 41.5 percent of the adults suffered from nightmares over these losses and that they drink more now. The most common manifestation of these symptoms was susto, a scare that causes the soul to leave the body, affecting 71 percent of men and 87 percent of women interviewed (Theidon and Del Pino 1997:64). Family violence associated with drinking has increased. Many complained of a terror of personal attack and persecution. Women no longer breast-feed their children, for fear of transmitting their fear and malignant memories. Such memories, they claim, will rot the brains of their children.

While it may be, as I have argued, that protest art is a vehicle for understanding the emergence of cultural hybridity and its articulation with the global culture market, new questions are raised by the picture of oppression and mental "dis-ease" that confronted me when I visited the sites of the violence. Village officials are denying military repression in order to receive what the state is offering. Forced forgetting has taken the form of bulldozing the dead out of the way for a new school. The new discourse of development has been set 


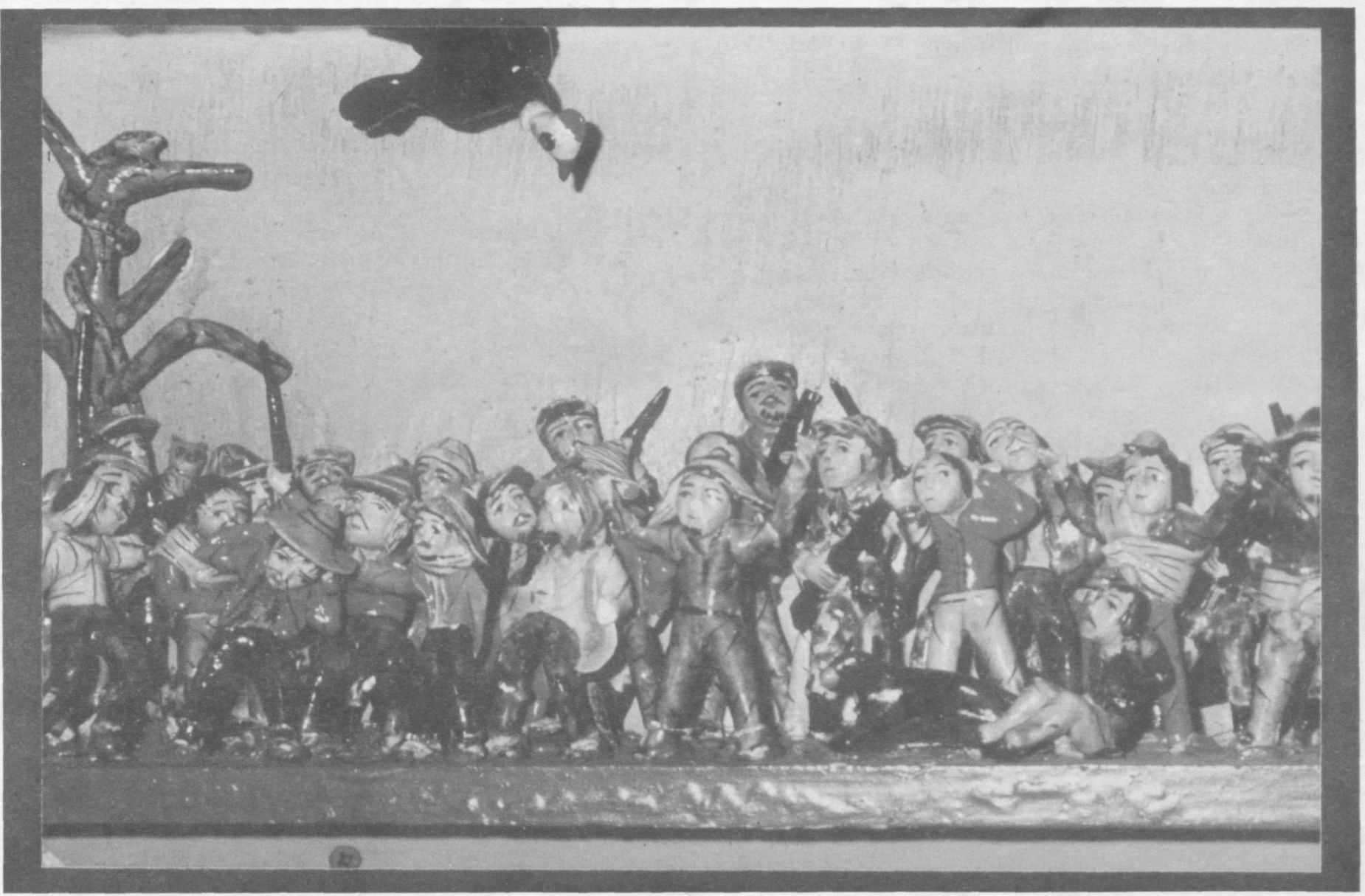

Figure 4

Sinchis round up peasants. Detail from retablo Sendero Luminoso en Ayacacho, by Severo Yaranga. Photo by Billie Jean Isbell.

in motion. All these contradictions must be set in dialogue with one another.

BILLIE JEAN ISBELL is a professor in the Department of Anthropology, Cornell University, Ithaca, NY 14853.

\section{Note}

Acknowledgments. I would like to thank the following Cornell institutions for their support: the Latin American Studies Program, the MacArthur Foundation grant through the Peace Studies Program, and the Cornell International Institute for Food and Development. Several colleagues have read and made comments on drafts and presentations of this essay: Catherine Allen, Michelle Bigenho, John Borneman, Regina Harrison, and Bruce Mannheim. I also wish to thank John Cohen and Nicario Jiménez for tapes of contemporary Huaynos, among them, "Democracy and Liberty," performed and recorded by Chakitukus, a music group from Chuschi. Luis Morató transcribed and translated the Quechua text for me as a starting point for my own transla- tions. Hans Buechler reminded me that the lizard is a symbol of the unknown.

\section{References Cited}

Araujo, Hilda

1993 Parentesco en Sarhua, Perú: Descripcion y representación icongráfic. Paper presented at symposium Kinship and Gender in the Andes, St. Andrews, Scotland, September.

Attinasi, John, and Paul Friedrich

1995 Dialogic Breakthrough: Catalysis and Synthesis in Life-Changing Dialogue. In The Dialogic Emergence of Culture. D. Tedlock and B. Mannheim, eds. Pp. 33-53. Urbana: University of Illinois Press.

García Canclini, Nestor

1995 Hybrid Cultures: Strategies for Entering and Leaving Modernity. Christopher L. Chiappari and Silvia L. Lopez, trans. Minneapolis: University of Minnesota Press. 
292 american Anthropologist • Vol. 100, No. 2 • June 1998

Haraway, Donna

1991 Simians, Cyborgs and Women. New York: Routledge.

Huamantinco Cisneros, Francisco 1990 Los refugiados intemos en el Perú. Lima: Ed. Publicidad de Comercio Exterior.

Isbell, Billie Jean

1985 To Defend Ourselves. 2nd edition. Prospect Heights, IL: Waveland Press.

1992 Shining Path and Peasant Responses in Rural Ayacucho. In Shining Path of Peru. David Scott Palmer, ed. Pp. 59-82. New York: St. Martin's Press.

1994 Shining Path and Peasant Responses in Rural Ayacucho. In Shining Path of Peru. 2nd edition. David Scott Palmer, ed. Pp. 59-82. New York: St. Martin's Press.
Mannheim, Bruce, and Dennis Tedlock

1995 Introduction. In The Dialogic Emergence of Culture. D. Tedlock and B. Mannheim, eds. Pp. 1-32. Urbana: University of Illinois Press.

Rosaldo, Renato

1995 Foreword. In Hybrid Cultures: Strategies for Entering and Leaving Modernity. Nestor García Canclini. Pp. i-xii. Minneapolis: University of Minnesota Press.

Theidon, Kimberly, and Ponciano Del Pino

1997 Antropología y salud mental: Un estudio en la recuperacion comunal. Ayacucho, Peru: Informe Final.

Thomas, Michael

N.d. Andean Peasants in the Labyrinth of Power: A Mythic Representation of National and Regional Hegemony in Cuzco, Peru. Unpublished MS. 